\title{
Medical Plant Species: Distribution, Traditional Utilization, Conservation and Role in Tourism Development in the Forest of Taman Gumi Banten, Wanagiri Village, Buleleng, Bali
}

\author{
Nyoman Wijana ${ }^{1, *}$, Desak Made Citrawathi ${ }^{1}$, Sanusi Mulyadiharja ${ }^{1}$, Ketut Srie Marhaeni Julyasih ${ }^{2}$, \\ Ni Putu Sri Ratna Dewi ${ }^{1}$
${ }^{1}$ Biology Education Study Program, Department of Biology and Marine Fisheries, Faculty of Mathematics and Natural Sciences, Universitas Pendidikan Ganesha, Indonesia
${ }^{2}$ Biology Study Program, Department of Biology and Marine Fisheries, Faculty of Mathematics and Natural Sciences, \\ Universitas Pendidikan Ganesha, Indonesia
}

Received September 9, 2021; Revised November 9, 2021; Accepted November 23, 2021

\section{Cite This Paper in the following Citation Styles}

(a): [1] Nyoman Wijana, Desak Made Citrawathi, Sanusi Mulyadiharja, Ketut Srie Marhaeni Julyasih, Ni Putu Sri Ratna Dewi, "Medical Plant Species: Distribution, Traditional Utilization, Conservation and Role in Tourism Development in the Forest of Taman Gumi Banten, Wanagiri Village, Buleleng, Bali," Environment and Ecology Research, Vol. 9, No. 6, pp. 340 - 361, 2021. DOI: 10.13189/eer.2021.090603.

(b): Nyoman Wijana, Desak Made Citrawathi, Sanusi Mulyadiharja, Ketut Srie Marhaeni Julyasih, Ni Putu Sri Ratna Dewi (2021). Medical Plant Species: Distribution, Traditional Utilization, Conservation and Role in Tourism Development in the Forest of Taman Gumi Banten, Wanagiri Village, Buleleng, Bali. Environment and Ecology Research, 9(6), 340 - 361. DOI: 10.13189/eer.2021.090603.

Copyright $\odot 2021$ by authors, all rights reserved. Authors agree that this article remains permanently open access under the terms of the Creative Commons Attribution License 4.0 International License

\begin{abstract}
Taman Gumi Banten Forest is located in Wanagiri Village, Sukasada District, Buleleng Regency, Bali Province. This forest was previously managed by the local government. When managed by the government, illegal logging occurred and expansion of cultivated plants into the forest. The government then grants the forest for its management to the customary village. The forest that is managed by this customary village is based on local wisdom so that this forest remains sustainable until now and there is no illegal logging and expansion of cultivated plants into the middle of the forest. The purpose of this study was to determine the various species of medicinal plants and their mapping in the perspective of traditional medicinal plant use, processing methods, usage methods, designation of medicinal plants, tourism perspectives, and local wisdom-based conservation. The research population was all plant species in the forest of Taman Gumi Banten. The research sample for (1) mapping study was the entire forest area of Taman Gumi Banten. (2) Plant species samples are all plant species covered by squares with a size of $20 \times 20 \mathrm{~m}^{2}$ (for trees), $5 \times 5 \mathrm{~m}^{2}$ (for saplings), and $1 \times 1 \mathrm{~m}^{2}$ for seeds /
\end{abstract}

seedlings). To find out the various types of plants that can be used as medicinal plants, deep interview methods, observation, questionnaires, and check lists are used. The informants were Balian / Shaman (2 people), Village Head and staff (5 people), Traditional Village Head staff (5 people), Stakeholders / Pastors (3 people), General Community (10 people). Total informants were 25 people. The collected data were analyzed descriptively. The results showed: (1) The overall plant species and medicinal plants in the Taman Gumi Banten forest, Wanagiri Village, Sukasada District, Buleleng Regency have been mapped. (2) The traditional use of medicinal plants by the Balinese people generally has three properties, namely tis (cold), dumelade (not cold and not hot), and anget (hot). (3) In the perspective of developing forest tourism, there are opportunities to be developed as a tourism object.

Keywords Medicinal Plants, Species Distribution Map, Conservation, Wanagiri 


\section{Introduction}

Mapping is an effort to convey, analyze, and classify the data in question, as well as convey it in the form of a map easily giving a clear picture. Mapping that has a special purpose is often called a thematic map, a map that is made according to needs. In general, what is important in thematic maps is the presentation of data in the form of symbols, because symbols convey the contents of the map and as a medium of good communication between map makers and map users. Mapmakers must try to make symbols that are simple, easy to draw but quite thorough, while for map users, symbols must be clear and easy to read or understand [1]. Maps are a very important means of conducting research related to plant ecology, because they contain information about the geographic area of an area and the positions of objects. In the context of developing forest areas, physical / socio-economic data, field surveys, aerial / satellite imagery and literature that have been collected, are analyzed then some of the data is presented / manifested in the form of thematic maps using various scales according to needs. The distribution of the location of a plant, field data is needed which is obtained through measurements with auxiliary points. These auxiliary points are needed to determine triangulation points which have fixed coordinates. In connection with this, auxiliary points are needed so that they can map an area in detail. This series of auxiliary points is called a polygon [2]. On the compass polygon, the start and end points must coordinate. In the same system, to be able to correct the correctness of distance measurements [3]. In this study, a mapping method was used which was carried out with a simple measurement technique.

The definition of medicinal plants or medicinal plants has been given by many experts. Likewise, in relation to research on medicinal plants, many have been carried out. The medicinal plant is all types of medicinal plants known or believed to have medicinal properties [4]-[5], which are grouped into: (1) Plants with traditional medicinal properties, namely; types of medicinal plants known or believed by the public to have medicinal properties and have been used as raw materials for traditional medicines. The traditional means of processing is carried out traditionally without any clinical and scientific trials. (2) Plants have modern medicinal properties, namely; types of plants scientifically proven to contain compounds or bioactive materials with medicinal properties and their use can be justified medically. Modern referred to is the method of processing which is carried out by means of clinical and scientific trials, and (3) Plants with potential medicinal properties, namely; types of medicinal plants suspected to contain compounds or active ingredients with medicinal properties, but have not been scientifically proven or their use as traditional medicines is difficult to trace.

The Ministry of Health of the Republic of Indonesia defines Indonesian medicinal plants as stated in the Minister of Health Decree No. 149 / SK / Menkes / IV / 1978, namely: (1) Parts of plants used as ingredients for traditional medicine or herbal medicine. (2) The part of the plant used as a starting material for medicinal raw materials (precursor), and (3) The part of the extracted plant used as medicine [6]. Nala [7] explains that the usada does not only contain diseases with plant ingredients, but also includes knowledge of medico-psychomatics, pharmacology, pharmacy, how to diagnose diseases, signs of pregnancy, caring for babies, good days for carrying out treatment, to signs that someone is going to die.

The traditional way of processing medicinal plants is by way of Ulig (crushed), Pakpak (chewed), Lablab (boiled), Fried, Nyahnyah/dioseng ((fried without oil), Tambus (put in hot flask), and Tunu (roasted). Likewise, if we look at the traditional use, namely Tetes (dropped), Tutuh (inserted through the nose), Loloh (drunk). In the way of treatment, traditional Balinese medicine is known to be used for external medicine by means of use including: Oles (rubbed on), Boreh (scrubbed), Simbuh (sprayed), Uap/Steam (anointed), Usug (compressed), Ses (wound cleansing), Limpun (sorted ), Kacekel (massaged), and Tampel (affixed) [8].

From the results of interviews with selected sources, namely Balian Usada/traditional healers and the community, the use of plants as drugs to eliminate certain diseases can be grouped into drugs for external diseases and medicines for internal diseases. As external medicine, for example burns, bruises, paralysis, swelling or brahma aiming, aches, itching, ear pain, in order to avoid evil aura and there is one interesting thing, namely as an antidote to negative people from shaman. Meanwhile, as drugs in, for example, drugs for dizziness, diarrhea, dysentery, liver, high blood pressure, ulcers, canker sores, dirty kidneys, allergies, and anti-fatigue drugs or stamina guards, drugs for drug addicts. The belief that develops in society divides diseases into three types, namely common diseases, magical diseases and diseases caused by food.

The use of medicinal plants as medicinal raw materials has been carried out by humans since the process of concocting was known and is still ongoing today. Medicinal plants are used by many people because they have relatively small side effects and are cheaper than chemical drugs. Budiharta et al. indicate that at least 30 species of Indonesian medicinal plants are now difficult to find in Indonesia [9]. While the latest data Cahyaningsih et al. records 38 species of rare medicinal plants in Indonesia [10]. Bappenas states that 44 medicinal plant species are categorized as rare [11]. This means that the presence of medicinal plants in nature continues to decline. Conservation measures to save the source of the medicinal plant germplasm

In the perspective of tourism development, the Taman Gumi Banten forest can be developed as a new tourism object oriented towards education on the introduction of medicinal plants, traditional processing methods, and 
conservation efforts based on local wisdom. This jungle tour is very unique and special. This kind of tourism development has not been developed in Bali. Some of the forests in Bali are used as tourism objects, such as the Monkey Forest, Gianyar, Alas Kedaton, Tabanan, forests in the village of Sangeh, Badung, Bali, where the tourism development is characterized by long-tailed monkeys. Tourism development in Bali related to ecotourism has not yet developed medicinal plant forests, and other useful plant species [12]-[13].

Previous research has been carried out on medicinal plants and their conservation can be seen in ref [14]-[15]. They are concerned about the preservation of medicinal plants in nature which have undergone a lot of degradation, so they do conservation in cultivated gardens, botanical gardens and national parks. However, the distribution of medicinal plants in their original nature has not been mapped, so it is difficult to conduct visitations, their sustainability, and educate the surrounding community.

This research was conducted in the Taman Gumi Banten forest, which is located in the village of Wanagiri, Sukasada District, Buleleng Regency. Overall study is taking the topic of mapping the whole plant and medicinal plants in particular. In the study discussion, this article is devoted to the mapping of medicinal plants, traditional medicinal plants utilization, processing methods, usage methods, designation of medicinal plants, tourism perspectives, and conservation based on local wisdom.

\section{Research Methods}

The location of this research is in the forest of Taman Gumi Banten, Wanagiri Village, Sukasada District, Buleleng Regency, Bali Province (See Figure 1).

This type of research is included in exploratory research. The research population was all plant species in the forest of Taman Gumi Banten [16]. The research sample for (1) mapping study was the entire forest area of Taman Gumi Banten. (2) Plant species samples are all plant species covered by squares with a size of $20 \times 20 \mathrm{~m}^{2}$ (for trees), $5 \times 5$ $\mathrm{m}^{2}$ (for saplings), and $1 \times 1 \mathrm{~m}^{2}$ for seeds/seedling) (See Figure 2).

\subsection{Mapping of Medicinal Plant Species}

The mapping method is carried out using a simple measurement technique on a simple mapping note of maps and boundary layouts [17]. Mapping work steps:

1. Doing temporary point erection by determining the measuring point (stakes). The points made in the field must be easily found, these points are marked with a wood (stake) with a size of $15 \times 15 \mathrm{~cm} 2$ which is planted in the ground, then the logs must be numbered with a dot and above it.
2. Measuring the distance directly through the distance between wooden stakes using a length measuring device equipped with lines along with the number of meters. When doing distance measurement, the tool is placed horizontally so that the distance is measured accurately.

3. Calculating the difference in ground level with heling at each distance between the wooden pegs. Perform simple definitive measurements using the compass polygon method of the slide system. (a) Measurement of angles or azimuths is carried out on each wooden stake that has been placed at the location points to form a closed polygon. (b) Calculating the coordinates of the compass polygon point by knowing the coordinates of the starting and ending points, then determining the geographic azimuth.

4. The scattering of medicinal plant species is carried out by the exploratory method by collecting data on plant species using the Global Positioning System (GPS) to determine the location of the plants presented in the medicinal plant distribution map. The data that have been collected are then analyzed descriptively.

\subsection{Collecting Data on Medicinal Plant Species}

Observation of medicinal plant species in Taman Gumi Banten, uses the quadratic method with a systematic sampling technique [18]. The stages of data collection of plant species in the field are as follows.

1. To divide and demarcate the area in the forest of Taman Gumi Banten. The forest study area of Taman Gumi Banten is divided into 2 zones, namely Zone I and Zone II.

2. Placing the transect line as a compass line in the study area.

3. Each zone is placed in a square measuring $20 \times 20$ until the study limit is determined with an interval between squares of 10 meters with a total of 100 squares. The position of each square on the transect line is placed on the left and right alternately and continuously. To clarify the position of the square in each zone, shown in the following Figure 5 .

4. Collecting data on the number of individual plant species covered in squares in each zone into a work table.

5. Documenting each plant species that has been researched and don't forget to take a sample of that species and put it in a plastic bag that has previously been labeled for herbarium specimens. The herbarium specimens were subsequently identified at the Biology Laboratory, Faculty of Mathematics and Natural Sciences, Ganesha University of Education and at the Ekakarya Botanical Gardens, Bali. 


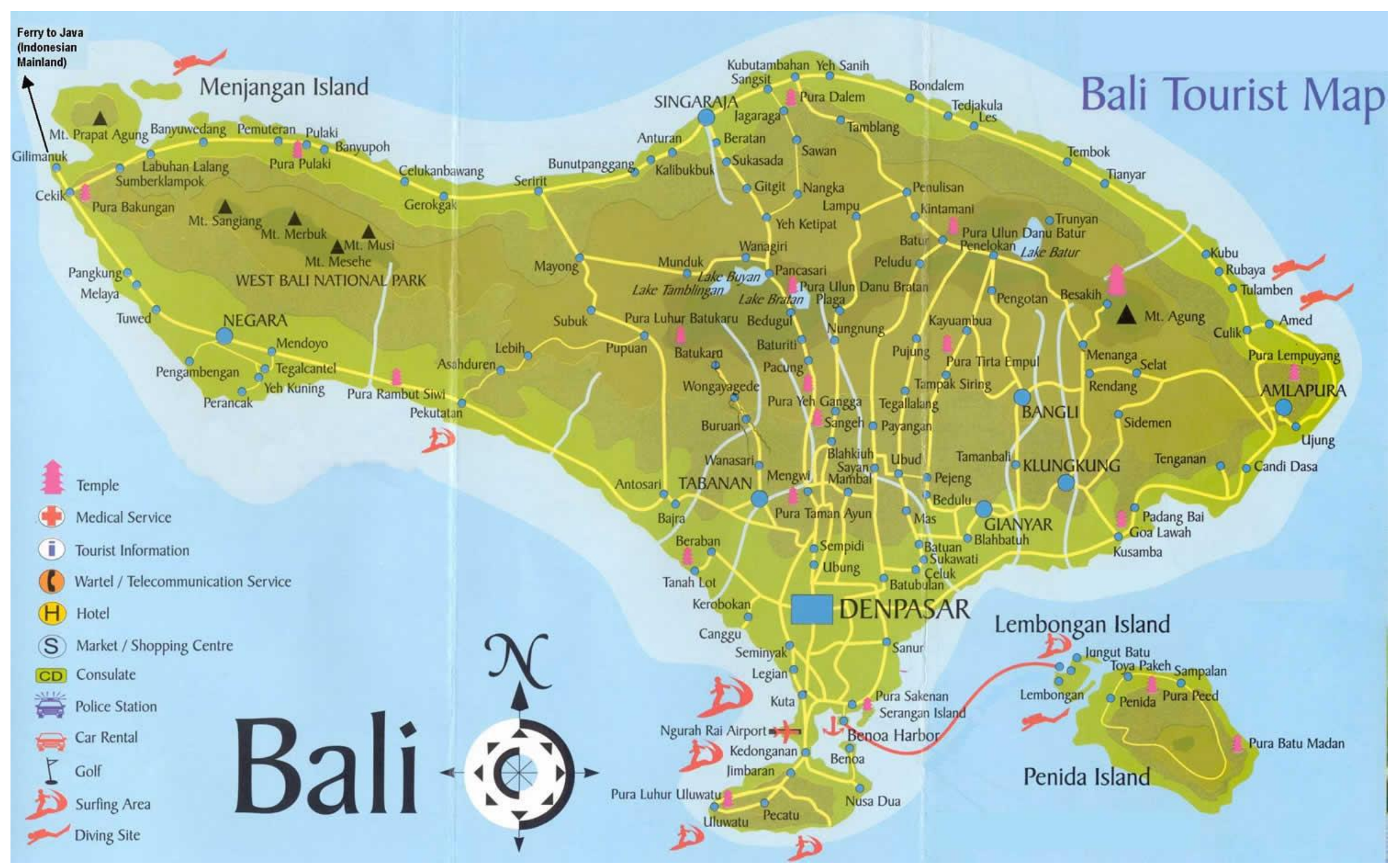




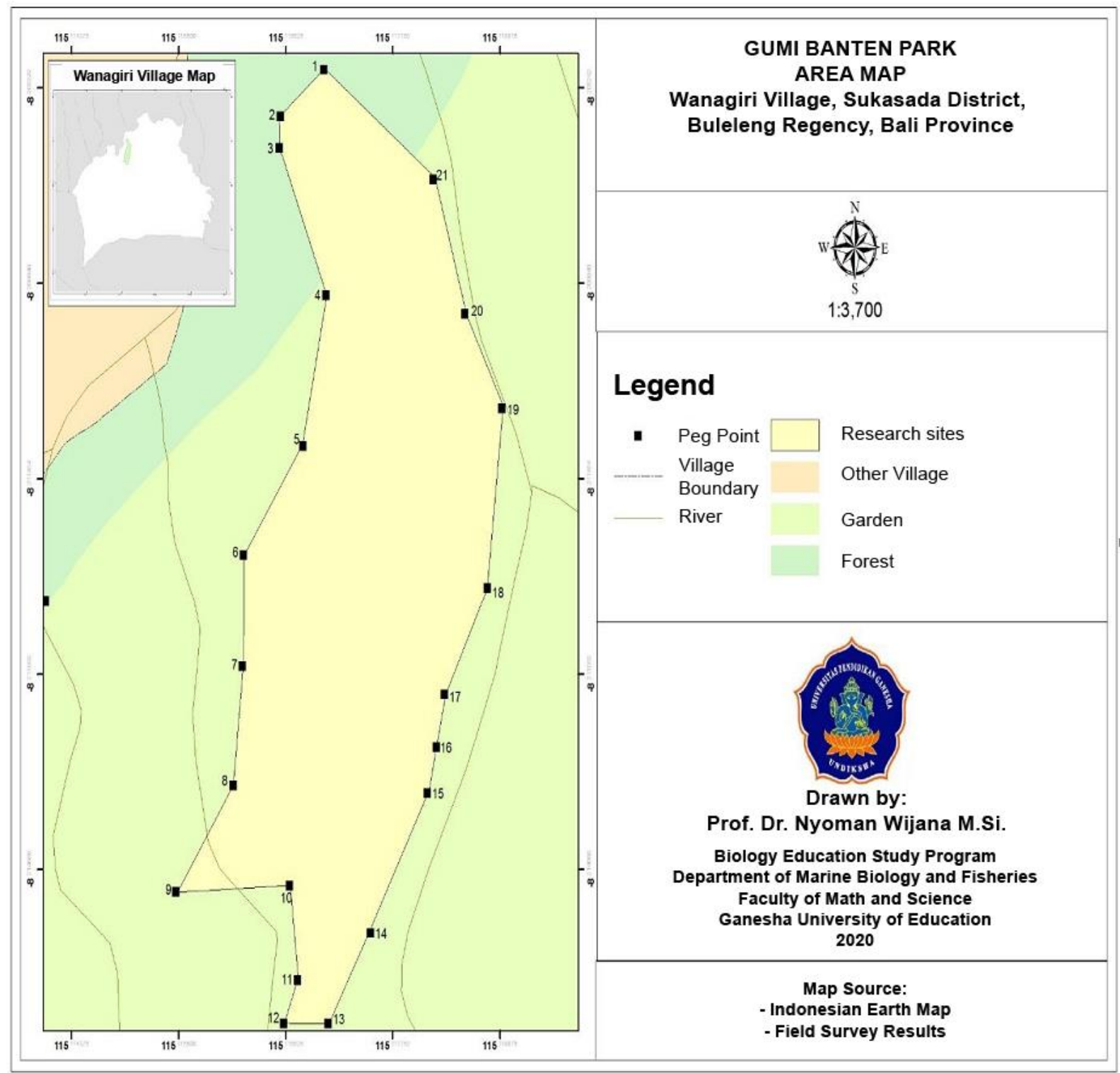

B

Figure 1. A. Bali Island and Wanagiri Village. B Map of Research Locations in the Taman Gumi Banten Forest 


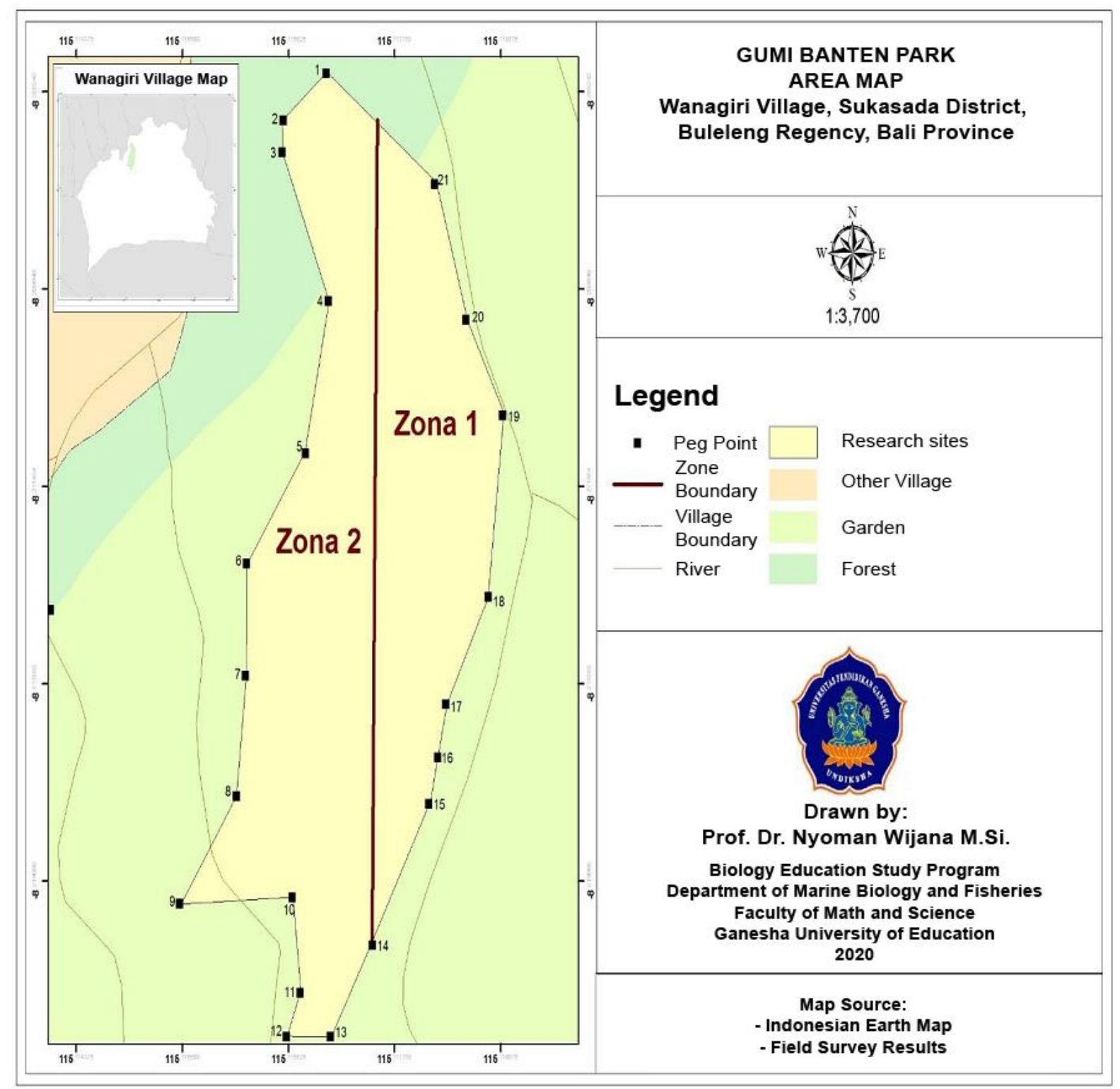

A 


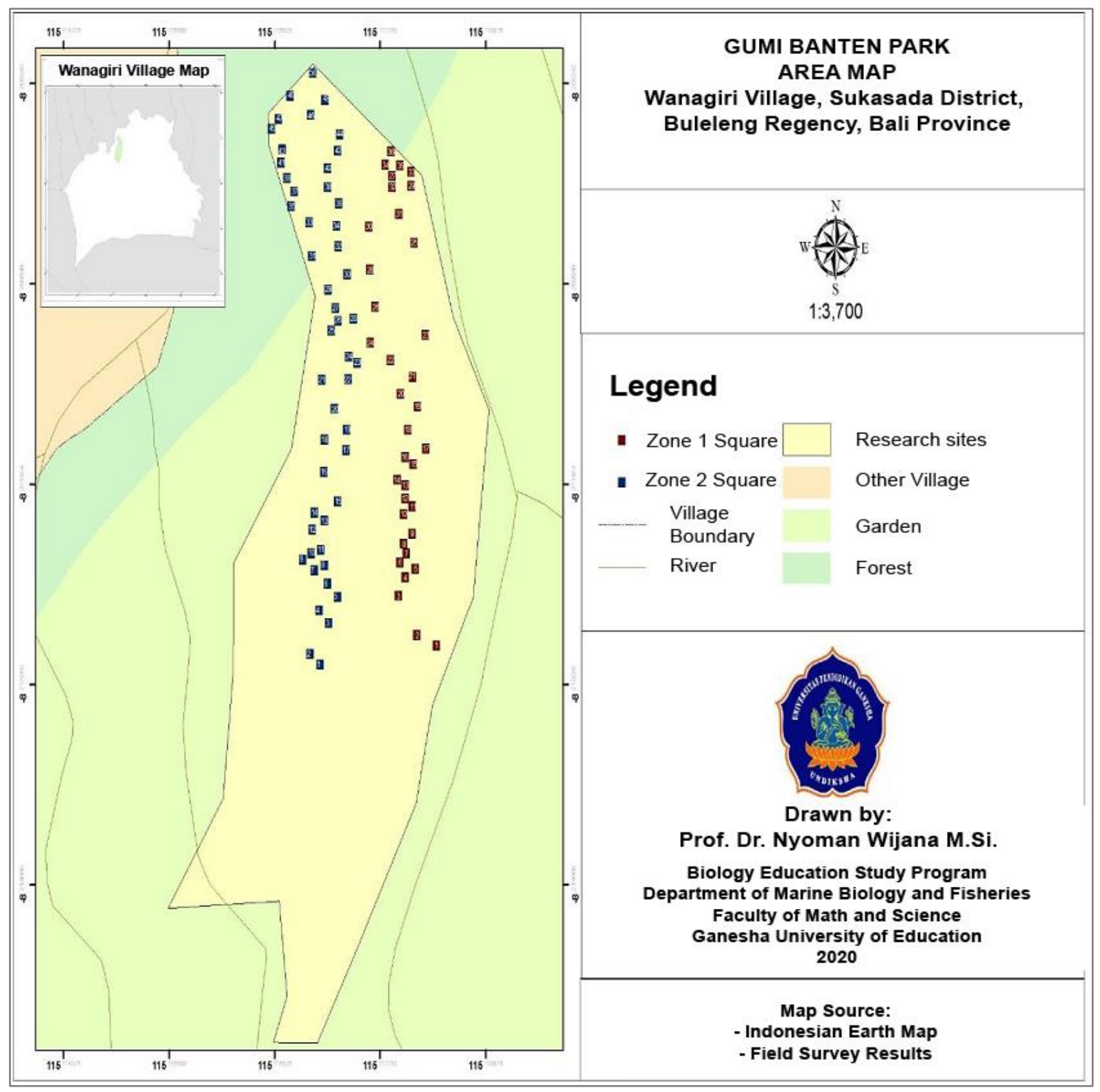

B

Figure 2. A. The Research Location is Divided Into 2 zones. B. Position of Squares in Each Zone 


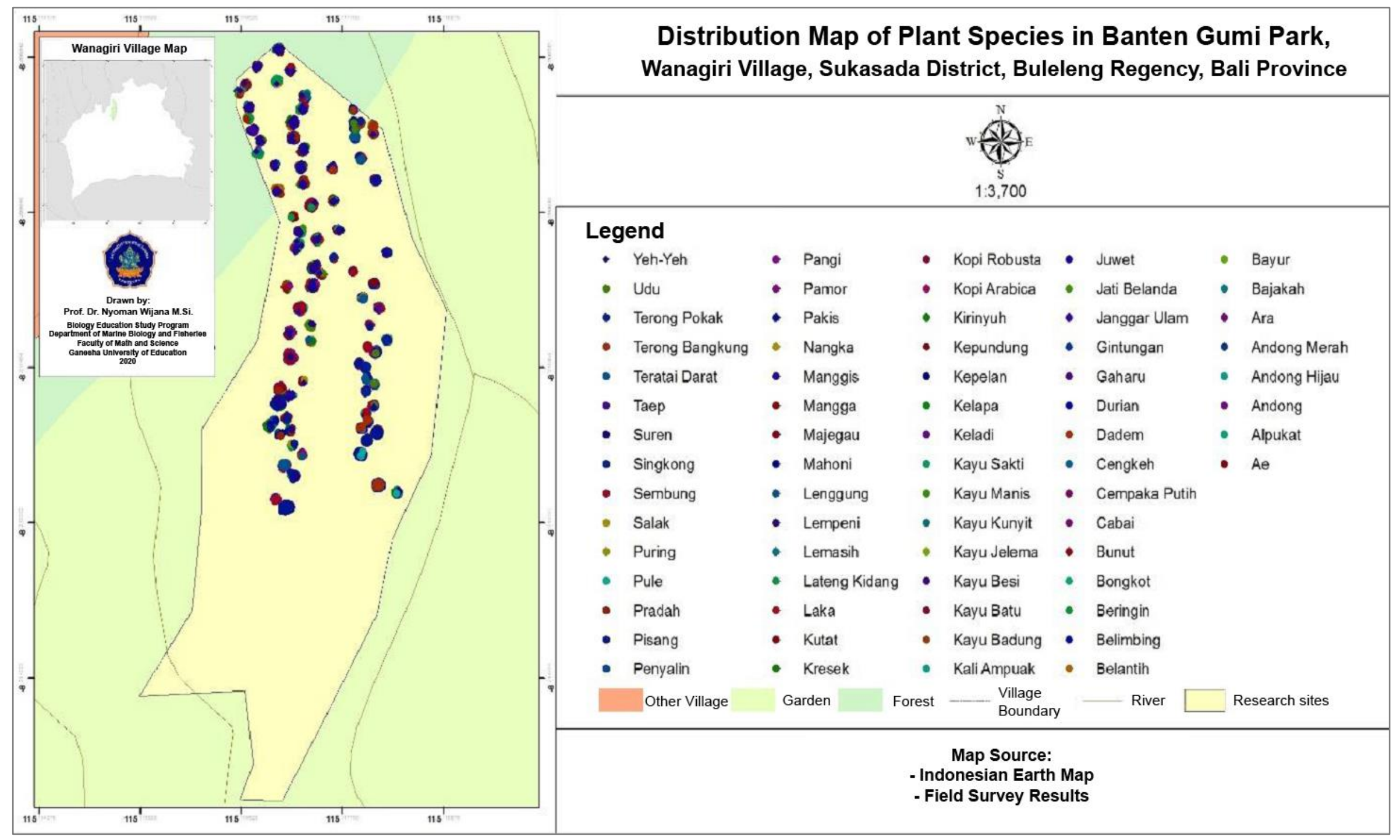

Figure 3. Map of Distribution of All Plant Species in the Taman Gumi Banten forest 


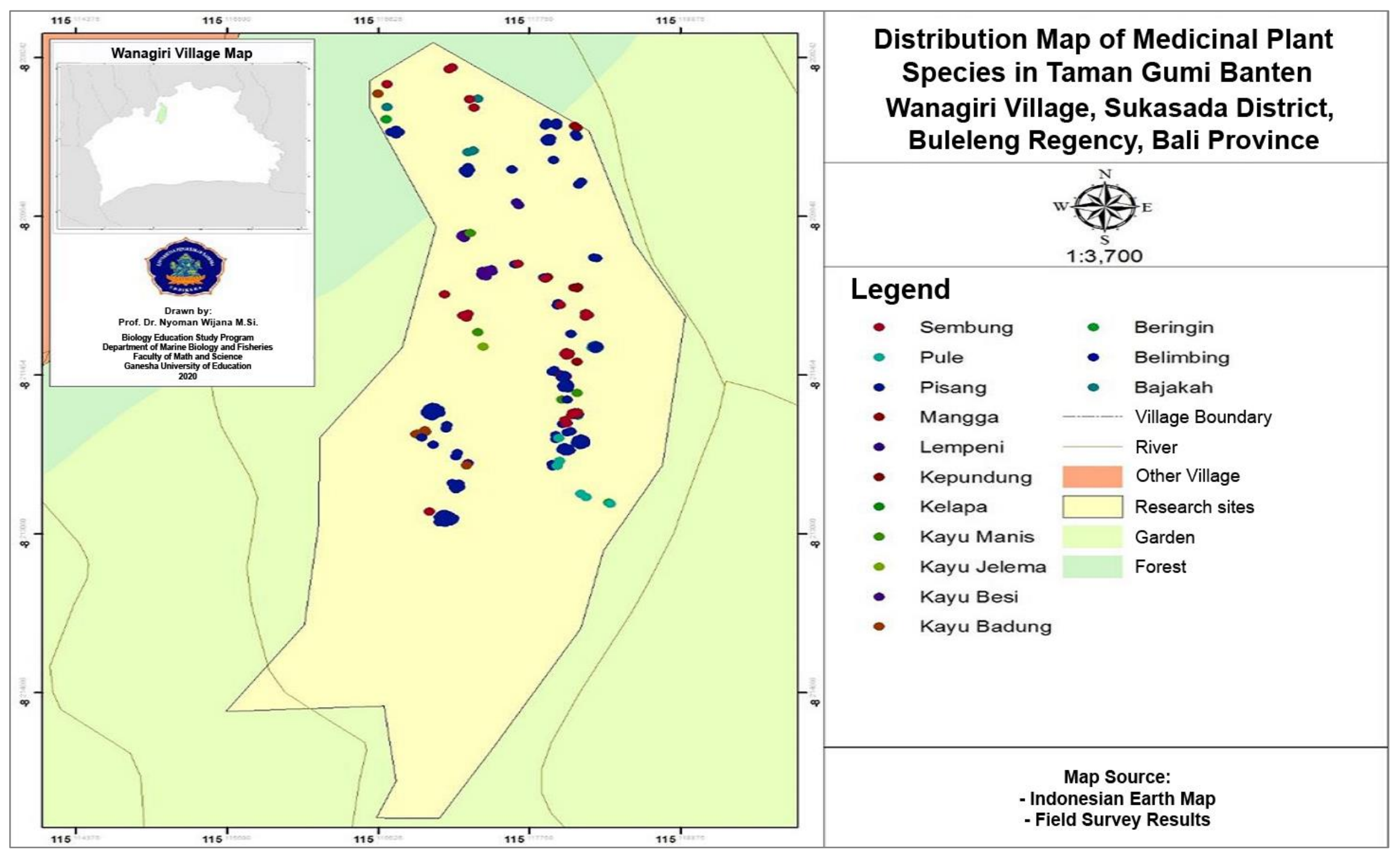

Figure 4. Map of the Distribution of Medicinal Plants in the Taman Gumi Forest Banten 


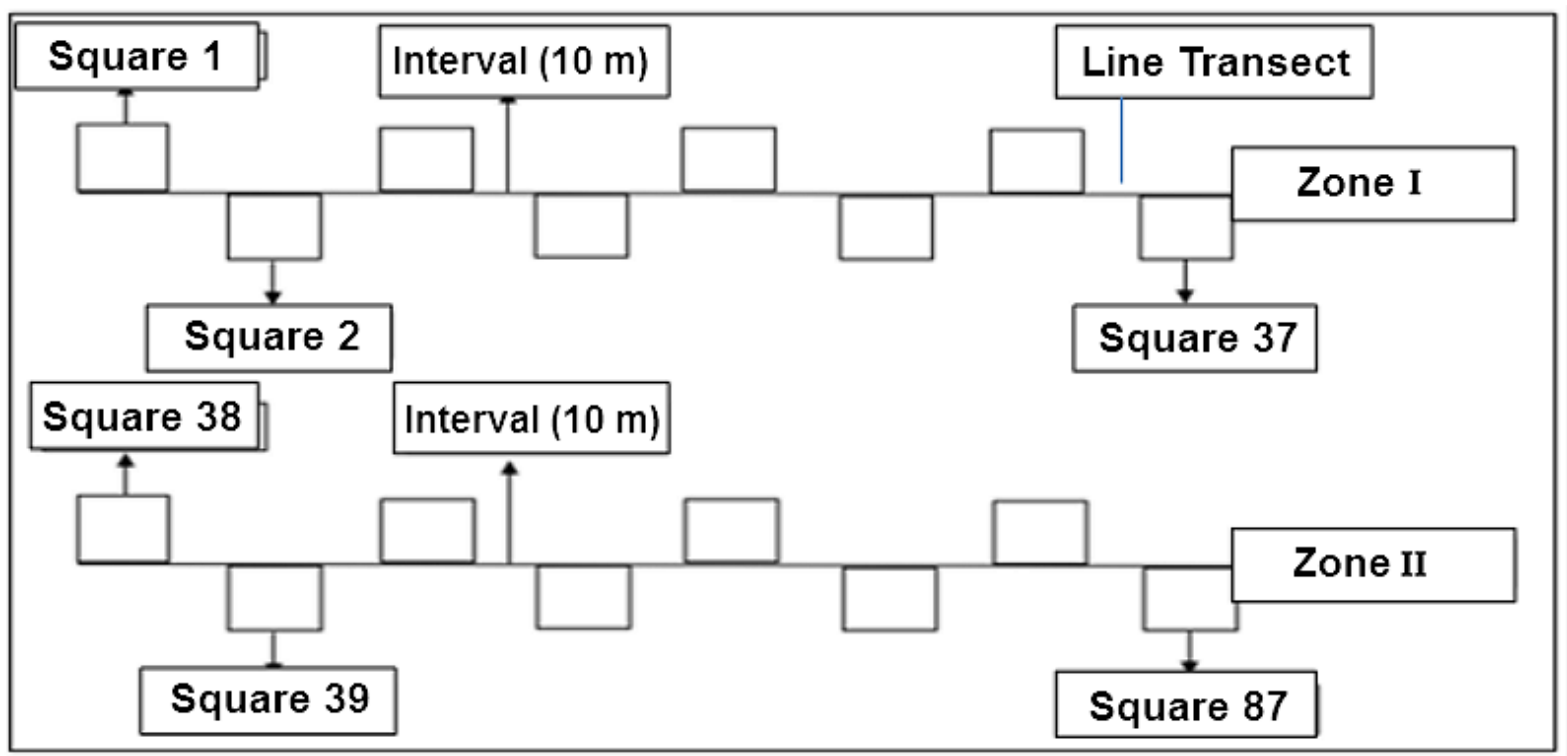

Figure 5. Schematic of Square Position in Plant Species Sampling

The collected data are entered into a work table. From these data, it will be seen the composition of plant species in general in the forest of Taman Gumi Banten. From the results of the observation of the plant as a whole, arranged plant species that can be used as medicinal ingredients according to the experience of the people of Wanagiri Village in particular and the Balinese people in general. To find out the various types of plants that can be used as medicinal plants, in-depth interviews, observations, questionnaires, and check lists were used. The sample of respondents included Village Heads and Staff (5 people), Traditional Village Heads and Staff (5 people), Stakeholders/Priests (3 people), General Community (12 people). The total respondents were 25 people. The data collected were analyzed descriptively.

\section{Results and Discussion}

\subsection{Plants in General and Their Mapping}

The results of this research on plants in the Taman Gumi Banten forest: In Zone I, 27 species of plant species at the tree level, 24 species of sapling, 14 species of seedling. In species combined, there are 48 species of tree, sapling and seedling. In zone II there are 30 species at tree level, 27 species at sapling level and 27 species at seedling level, and there are 48 species combined at tree level, sapling and seedling level. Based on the overall species data (combined zone I and zone II) it can be stated that the number of plant species at the tree level is 38 species, sapling 43 species, and seedling 36 species. The total plant species in the Taman Gumi Banten forest are as many as 67 species.

From the 67 plant species in the forest of Taman Gumi
Banten, 59 species $(88.06 \%)$ can be used by the local community, while 8 species (11.94\%) have yet to be used. Plants that have not been used by the community is because traditionally their benefits have not been known either as materials for clothing, boards, food, medicines, Hindu religious ceremonies or for industrial purposes. From the 59 species of useful plants or those used by the local community, 23 species (38.98\%) are used for food, 20 species $(33.89 \%)$ are used for boards, 9 species $(15.25 \%)$ are used for medicine, 23 species $(38,98 \%)$ for ceremonial materials and 1 species $(1.69 \%)$ for industrial materials. Meanwhile, the utilization of clothing is 0 or none. The overall distribution map of plant species in the forest of Taman Gumi Banten is presented in Figure 3.

Figure 3 shows the mapping results of all plant species in the study area covered by squares. There are 67 species of plants found at the research location, with the number of individual species as many as 1,501 individuals. Based on the results of density calculations, there were 348 individual species of tree, sapling, and seedling categories. From the description of the number of species and the number of individuals depicted on the map, it gives an impression that the distance to the growing point of the individual species is very dense. Even on the adjacent GPS, it looks like it's overlapping.

\subsection{Medicinal Plant Species and Their Mapping}

List of medicinal plant species in the Taman Gumi Banten forest, which are used by the Wanagiri village community in particular and the Balinese people in general, is presented in Table 1.

From the medicinal plants in the Taman Gumi Banten forest, the distribution of their growth points is depicted in the medicinal plant mapping as shown in Figure 4. The 
distribution of coordinate points is presented in Table 2.

The map image of medicinal plant species above is the result of mapping medicinal plants in the research location. 9 species of medicinal plants have been discovered and mapped, including Sembung wood (Blumea balsamifera DC), Cinnamon (Cinnamomum zeylanicum Ness), Bajakah (Spatholobus littoralis Hassk), banyan (Ficus benjamina L), Banana (Musa paradisiaca L), Jeleme wood (Knema glauca Warb), Starfruit (Averrhoa carambola L), Pule (Alstonia Scholaris R.BR), and Coconut (Cocos nucifera $\mathrm{L}$ ).

Banana plants are very abundant in the forests of Taman Gumi Banten, Wanagiri village. Based on the history of forest management in Taman Gumi Banten, before being managed by the village, the forest was managed by the government. At that time there was illegal logging and expansion of cultivation of cultivated plants in the middle of the forest by the community around the forest. Therefore, banana plants are very much found in the middle of the forest. As for the Jeleme wood (Knema glauca Warb) medicinal plant, which is a native plant growing in the forest, the number of individuals is very small, namely only one tree. This is related to the status of Jeleme Wood (Knema glauca Warb), a rare plant. This plant has a characteristic that is the sap is red, like human blood, so that local people call it Human Wood.

Table 1. Species of Medicinal Plants in the Taman Gumi Banten Forest

\begin{tabular}{|l|c|c|c|}
\hline No & Local Name & Scientific Name & Family \\
\hline 1. & Kayu Sembung & Blumea balsamifera DC & Euphorbiaceae \\
\hline 2. & Kayu Manis & Cinnamomum zeylanicum Ness & Fabaceae \\
\hline 3. & Bajakah & Spatholobus littoralis Hassk & Moraceae \\
\hline 4. & Beringin & Ficus benjamina L & Musaceae \\
\hline 5. & Pisang & Musa paradisiaca L. & Lauraceae \\
\hline 6. & Kayu Jeleme & Knema glauca Benth. Warb. & Oxalidaceae \\
\hline 7. & Belimbing & Averrhoa carambola L & Apocinaceae \\
\hline 8. & Pule & Alstonia scholaris R.BR & Arecaceae \\
\hline 9. & Kelapa & Cocos nucifera & 8 families \\
\hline 10. & TOTAL & 9 species & \\
\hline
\end{tabular}

Table 2. Examples Coordinate Points (X, Y) of Medicinal Plants in the Taman Gumi Banten Forest, Wanagiri Village

\begin{tabular}{|c|c|c|c|c|c|}
\hline \multirow[t]{2}{*}{ No } & \multirow[t]{2}{*}{ Species name } & \multirow{2}{*}{$\begin{array}{l}\text { Number of } \\
\text { Individual } \\
\end{array}$} & \multicolumn{2}{|c|}{ Coordinate } & \multirow[t]{2}{*}{ Information } \\
\hline & & & $\mathrm{X}$ & $\mathrm{Y}$ & \\
\hline \multirow[t]{2}{*}{1} & $\begin{array}{c}\text { Kayu Sembung (Blumea balsamifera } \\
\text { DC) }\end{array}$ & 1 & 115.118014 & -8.211910199 & Seedling \\
\hline & & 1 & 115.1180249 & -8.211945089 & Seedling \\
\hline \multirow[t]{2}{*}{2} & $\begin{array}{c}\text { Cinnanomon/Kayu Manis } \\
\text { (Cinnamomum zeylanicum Ness) }\end{array}$ & 1 & 115.1179932 & -8.211702336 & Sapling \\
\hline & & 1 & 115.1181065 & -8.211635534 & Sapling \\
\hline \multirow[t]{2}{*}{3} & Bajakah (Spatholobus littoralis Hassk) & 1 & 115.1180749075 & -8.2118457780 & Tree \\
\hline & & 1 & 115.1180946430 & -8.2118457780 & Tree \\
\hline \multirow[t]{2}{*}{4} & Banya/Beringin (Ficus benjamina $\mathrm{L}$ ) & 1 & 115.1183385 & -8.212744791 & Tree \\
\hline & & 1 & 115.116684579 & -8.20886847828 & Tree \\
\hline \multirow[t]{2}{*}{5} & Banana/Pisang (Musa paradisiaca L.) & 1 & 115.1179207 & -8.212358458 & Tree \\
\hline & & 1 & 115.1180224 & -8.212214554 & Sapling \\
\hline 6 & $\begin{array}{c}\text { Kayu Jeleme (Knema glauca Benth. } \\
\text { Warb.) }\end{array}$ & 1 & 115.1174078 & -8.211167802 & Tree \\
\hline 7 & $\begin{array}{c}\text { Belimbing Buluh (Averrhoa carambola } \\
\text { L) }\end{array}$ & 1 & 115.1172046529 & -8.2122747846 & Tree \\
\hline \multirow[t]{2}{*}{8} & Pule (Alstonia scholaris R.BR) & 1 & 115.1183508 & -8.212757478 & Sapling \\
\hline & & 1 & 115.1179726 & -8.212651865 & Tree \\
\hline 9 & Kelapa (Cocos nucifera $\mathrm{L})$ & 1 & 115.1179570 & -8.212360925 & Sapling \\
\hline
\end{tabular}

(Source: [19])

Note: For banana medicinal plants only a few coordinate points are taken, because the number of individual banana species is very large 
Table 3. The Medicinal Plants in the Taman Gumi Banten Forest Wanagiri Village

\begin{tabular}{|c|c|c|c|}
\hline No & Plant Species Name & Utilization Method & Product \\
\hline 1. & $\begin{array}{l}\text { Blumea balsamifera } \\
\text { DC (Kayu sembung) }\end{array}$ & $\begin{array}{l}\text { Sembung wood leaves can be used as a loloh drug, to treat stomach pain, } \\
\text { by: } \\
\text { Take enough sembung wood leaves. } \\
\text { Squeeze the leaves of the sembung with enough water. } \\
\text { Filter the water so that it is separated from the dregs of the leaves. } \\
\text { Filtered water is ready to drink. }\end{array}$ & \\
\hline 2. & $\begin{array}{l}\text { Cinnamomum } \\
\text { zeylanicum Ness } \\
\text { (Kayu manis) }\end{array}$ & $\begin{array}{l}\text { Cinnamon leaves can be used to treat heartburn / sore throat. } \\
\text { Look for cinnamon leaves to taste (the amount is not specified). } \\
\text { Clean the cinnamon leaves then boil with a little water and add a little salt } \\
\text { Grind the cinnamon leaves until crushed until the extras come out. } \\
\text { Filter it to find cinnamon leaf water, then you can drink it immediately. }\end{array}$ & \\
\hline 3. & $\begin{array}{c}\text { Spatholobus littoralis } \\
\text { Hassk } \\
\text { (Bajakah) }\end{array}$ & $\begin{array}{l}\text { Bajakah wood can be used as tea to treat cancer, by: } \\
\text { Crush the dried steel until it becomes very fine, forming tea powder. } \\
\text { If it has become tea powder, pour it with hot water for consumption. } \\
\text { Use a measure of } 1 \text { gram of Bajakah wood tea powder with } 500 \text { milli liters } \\
\text { of water. }\end{array}$ & \\
\hline
\end{tabular}

(Source: [19])

\subsection{Traditional Use of Medicinal Plants}

The use of medicinal plants, the designation of medicinal plants, and their processing methods by the Wanagiri village community in particular and the Balinese people in general are presented in Table 3.

Based on Table 3, it can be stated that of the 3 species for examples found in the Taman Gumi Banten Forest it can be used for external and internal medicinal purposes. For external medicine, it is used to reduce fever, cold (nyem), joint disease, paralysis and burns. For internal medicine, it is mainly used to treat stomach aches, heartburn / sore throat, cancer, high blood pressure, malaria drugs, coughs, gonorrhea, tonsillitis, acute colitis and heat seizures.

\subsection{Perspectives on Forest Tourism Development}

As the results of the research that have been presented above, we can further design the development of forest tourism in Taman Gumi Banten. Based on the Buleleng Regent Decree No. 430/405 / HK / 2017 where Wanagiri village is appointed as a tourism village so that the research results contribute to developing the Taman Gumi Banten forest as a complement to existing and existing tourism objects in the village. Operationally to develop forest tourism, where the tourism awareness group (PokDarwis) and local village tourism managers are given training to understand the vegetation map that has been produced in research and labeling medicinal plants in the middle of the forest so that tourists can easily recognize them. With the increase in tourism objects in the village, of course it will increase the welfare of the local community. Based on ref [19], the results of the SWOT analysis in the opportunities for developing forest tourism in Wanagiri village resulted in 8 strategies that could be developed. There are already several tourism objects in Wanagiri village, including waterfall tourism, temple tours for Balinese cuisine, Buyan Lake and Tamblingan Lake, Coffee Garden Tourism, Natural Scenery, Selfie Tourism, and Religious Tourism. All of the existing tourism objects provide a great opportunity to promote forest tourism which has its own uniqueness so that it can become a new tourism object.

\subsection{Perspectives in Conservation}

Mapping of medicinal plant vegetation and various medicinal plant species is obtained in this study, further in preserving the preservation of these medicinal plants, the local community applies local wisdom, religious aspects, myths, and awig-awig (customary village rules). Everything runs in synergy so that the preservation of forests and medicinal plants in particular can run as it should. This is to avoid repeating what happened before the forest was managed by the customary village.

There are several customary rules (awig-awig) that can be used as a reference in forest management so that it remains sustainable. The myth that is believed and used as a way of conservation is that the forest in the village of 
Wanagiri is a place for disposing of corpses, therefore this forest is seen by the community as a haunted forest. In addition, there is another myth which states that around one of the waterfalls, a beautiful goddess was inhabited. Based on sustainability which is based on the religiosity component, in local villages in particular and in Bali in general there is a special ceremony for plants. This holiday is called the Tumpek Uduh/Tumpek Arah/Tumpek Wariga holiday. Local wisdom of the local community shows that in felling wood or trees, people must find a good time or day. Before cutting down, you must planting plants as a substitute for the trees that are felled. At certain land slopes, trees may not be felled. This means that not at any time can cut wood so that time provides opportunities for tree growth to reach maturity. Planting plants as a substitute for felled plants is the basic concept of vegetation regeneration. The consideration of felling trees on certain slopes of land is a nature saving from the phenomenon of erosion or landslides.

\subsection{Discussion}

Vegetation mapping is very important for the Wanagiri community in particular and society as a whole. This is in line with the opinion expressed by the Ministry of Forestry (1984) which states that mapping contains information about the geography of an area and the positions of the objects that are mapped. Further, the forest mapping provides information and an overview of forest conditions can be seen in ref [20]. In this case, they researched the mapping of mangrove forest vegetation in the villages of Arakan, South Minahasa, North Sulawesi, the Wekas and Selo Hiking Trails of Mount Merbabu National Park, and mapping of green open spaces in Klaten Regency.

This mapping research has been widely supported by research conducted on ref [21], with mapping results as shown in Figure 6.

Figure 6 is a map of the distribution of rare plant species in Penglipuran forest, Bangli Regency (A), Alas Kedatorn forest, Tabanan Regency (B), and Mobkey Forest, (Gianyar Regency (C). In addition, the mapping of useful plant species in the traditional village of Tenganan Pegringsingan as presented in Figure 7.

There are 9 species of medicinal plants found in the forests of Taman Gumi Banten. The Monkey Forest, Gianyar, found 28 species of medicinal plants belonging to the Moraceae family (21\%) in the Gianyar Monkey Forest [22]. For medicinal plants in Tenganan Pegringsingan forest, Karangasem obtained $18(27.70 \%)$ species of medicinal plants. This is an indicator of the adaptation of plants to their environment. The low number of plant species in the forests of Taman Gumi Banten, Wanagiri Village cannot be separated from the history of forest management. The forest was managed by the government. At that time illegal logging occurred and expansion of cultivation of cultivated plants into the forest After 2015, with government policies in forest management, then based on the Bali Governor's Decree No. 2017/03-L / HK / 2005 dated 30 October 2015 that the management of the forest was handed over to the Wanagiri traditional village. Plant species that have already been used up in illegal logging cannot be returned, even cultivated plants are intensively used to obtain products from the forest. Forest reforestation has been carried out, but the plants used are mahogany (Swietenia mahagoni (L.) Jacq.

The traditional use of medicinal plants by Balinese people generally has three properties, namely tis (cold), dumelade (not cold and not hot), and has anget (hot) properties. Medicinal plants that are efficacious as above, based on the experience and findings on ref [7], which are relevant to several plants found in this study, are presented in Table 4.

The medicinal ingredients from plants are always added with other ingredients before they can be used to treat diseases [7]. In general, ingredients do not consist of only one type of plant material, but always more than one type of material. As one example of the use of the medicinal plant Pule, various ingredients are added so that it can only be used as a headache medicine [23]. The examples of traditional medicinal plants and potions mixtures can be seen in Table 5.

Scientifically, there are several species of medicinal plants whose chemical content is known to have medicinal properties [24]. In this case, one example is given of plants found in the forest of Taman Gumi Banten, where their chemical content has been found in Table 6 .

From Table 6 it appears that the medicinal plant Kayu Jelema (Knema glauca Benth. Warb) has no known chemical content. The results of the literature review have not shown any research on this plant. Only traditionally, this medicinal plant is used for the treatment of pain in joints and paralysis. In fact, traditionally in Bali it is used for "niskala" medicine or for disturbing spirits or bad people.

This research is also supported by the results of ethnobotanist research related to medicinal plants can be seen in refs [25]-[27]. The results of the research by ethnobotany experts can be concluded that in forest areas, botanical gardens, villages, and on an island, there are tens to hundreds of types of plants that can be used as ingredients in traditional medicine. The parts of plants that are most often used as ingredients in traditional medicine by the local community are the leaves, roots, bark, flowers, fruit, seeds, and sap. 


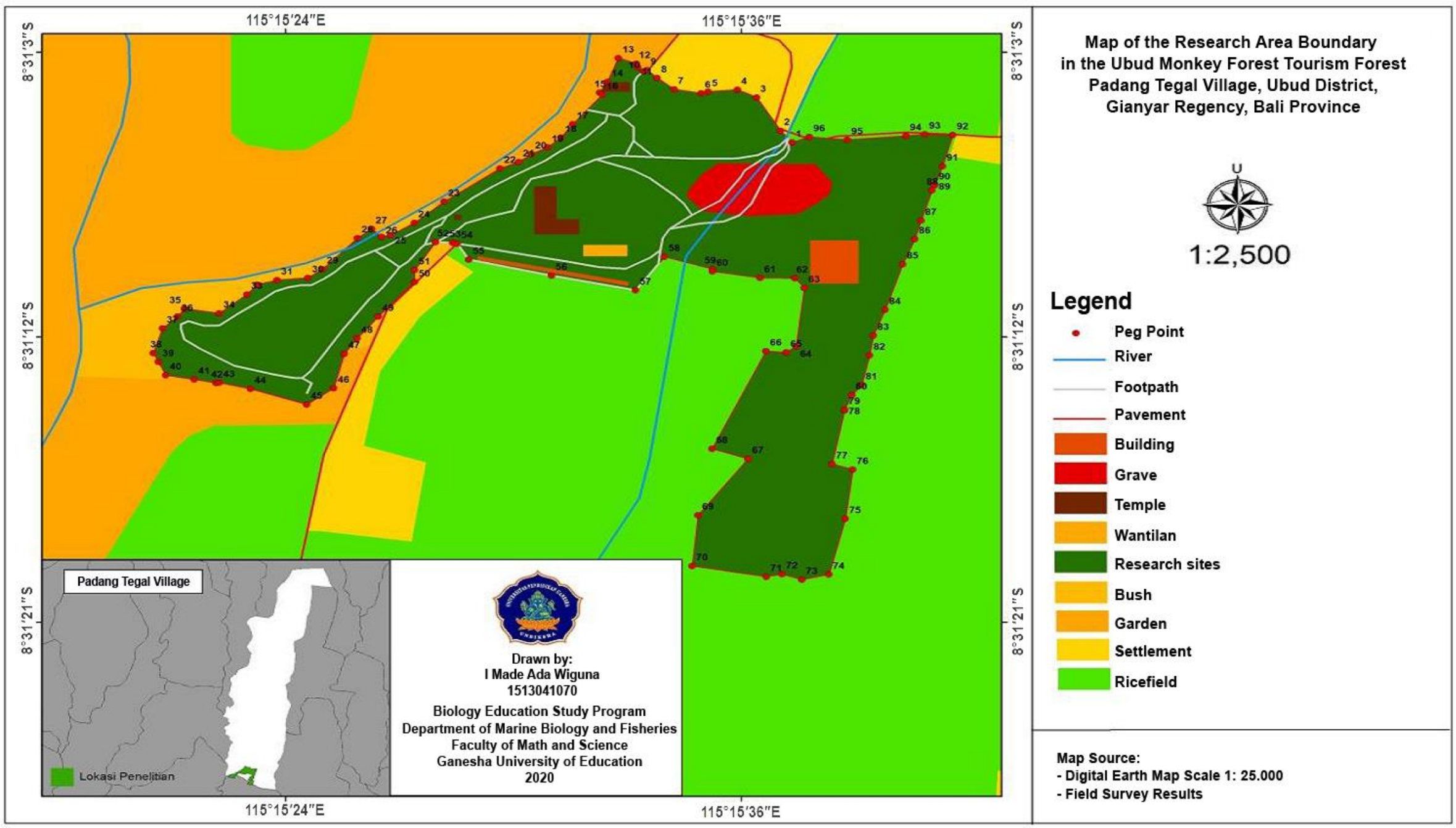

(A) 
Development in the Forest of Taman Gumi Banten, Wanagiri Village, Buleleng, Bali

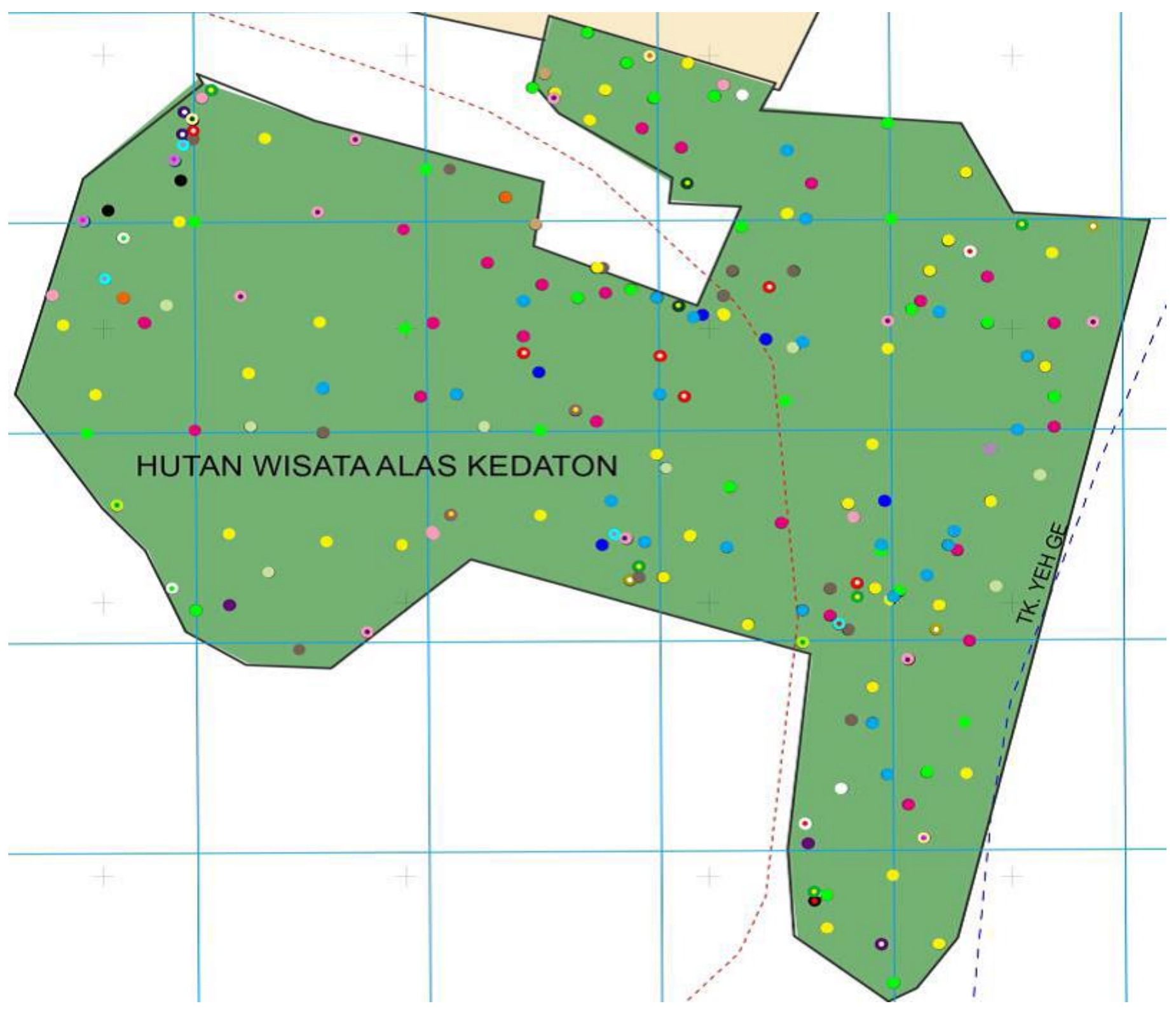


(B)

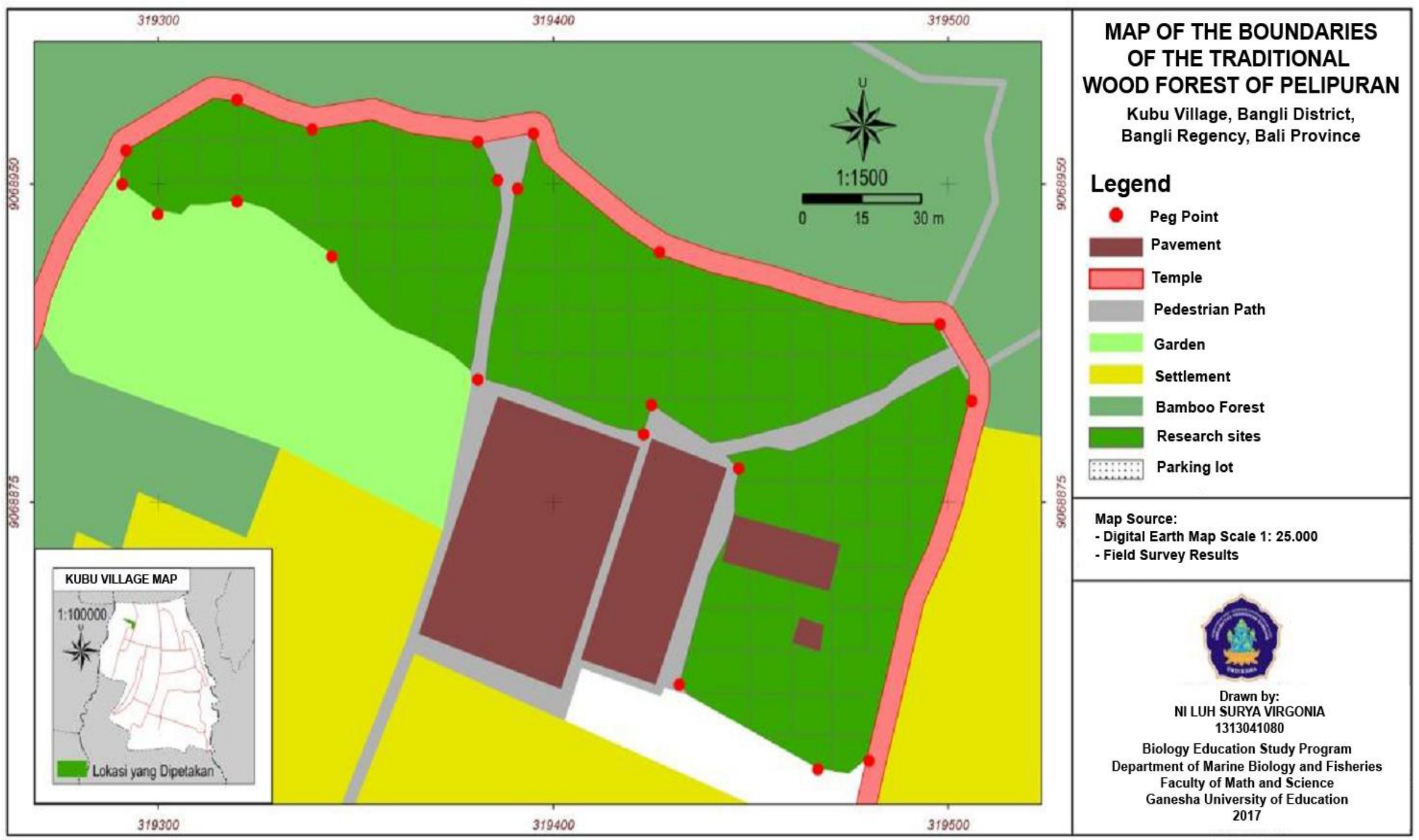

(C)

Figure 6. Distribution Map of Rare Plant Species. (A) Monkey Forest Forest, Gianyar. B Alas Kedaton Forest, Tabanan. C. Penglipuran Forest, Bangli 


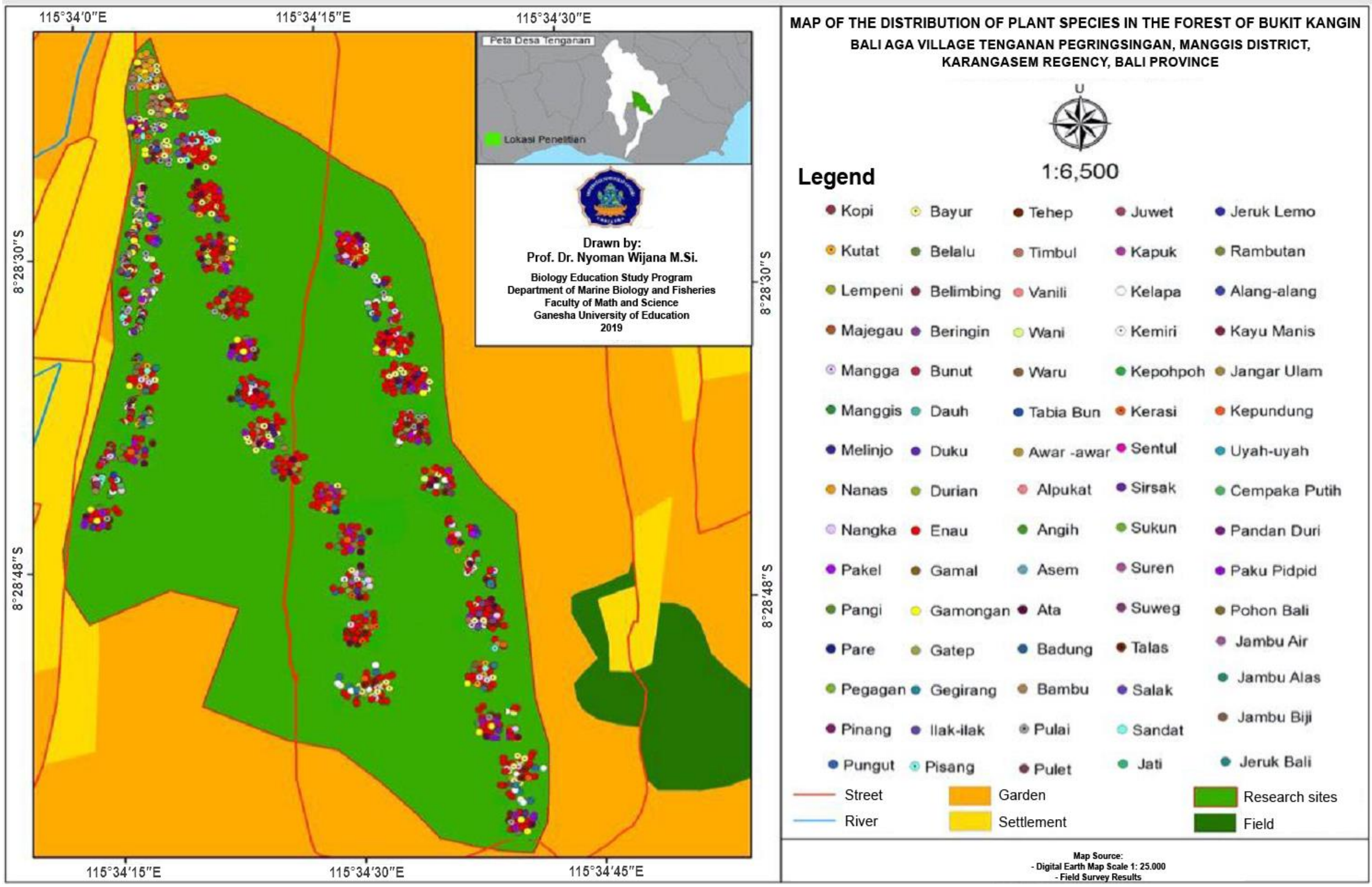

(A) 


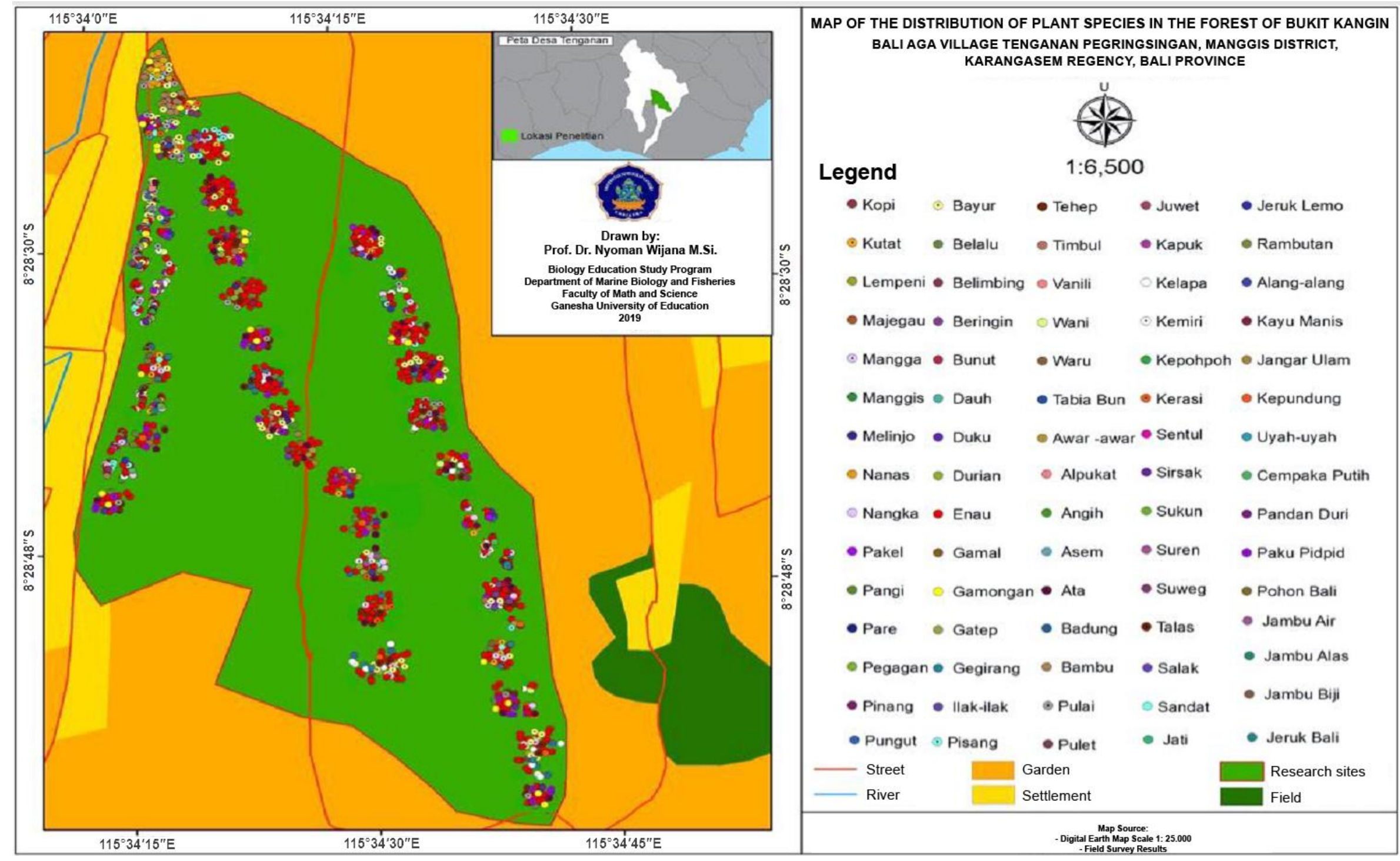

(B)

Figure 7. Map of Distribution of Plant Species as a Whole in the Forests of Bukit Kangin, Tenganan Pegringsingan, Karangasem (A), and Distribution Map of Useful Plant Species (B) 
Medical Plant Species: Distribution, Traditional Utilization, Conservation and Role in Tourism

Development in the Forest of Taman Gumi Banten, Wanagiri Village, Buleleng, Bali

Table 4. Medicinal Plants with their efficacy, and Types of Diseases Treated Traditionally

\begin{tabular}{|c|c|c|c|c|c|}
\hline No & Name of Plant & $\begin{array}{l}\text { Benefits of } \\
\text { Tis (cold) }\end{array}$ & $\begin{array}{c}\text { Benefits of Dumelada } \\
\text { (hot-cold) }\end{array}$ & $\begin{array}{l}\text { Benefits of } \\
\text { Anget (hot) }\end{array}$ & Medicine for Disease \\
\hline 1 & $\begin{array}{l}\text { Starfruit/Blimbing buluh } \\
\text { (Averrhoa carambola } \mathrm{L} \text { ) }\end{array}$ & - & bark & Roots & Cough, Shortness \\
\hline 2 & $\begin{array}{l}\text { Cinnamon/Kayu manis } \\
\text { (Cinnamomum zeylanicum } \\
\text { Ness) }\end{array}$ & $\begin{array}{l}\text { Roots, } \\
\text { leaves }\end{array}$ & - & - & $\begin{array}{l}\text { Hoarseness, indigestion, high blood } \\
\text { pressure, arthritis, skin allergies, } \\
\text { toothache, flu, correcting menstrual } \\
\text { irregularities; and for wound healing. }\end{array}$ \\
\hline 3 & $\begin{array}{l}\text { Coconut/Kelapa (Cocos } \\
\text { nucifera } \mathrm{L} \text {.) }\end{array}$ & - & Fruit juice & - & Deep heat \\
\hline 4 & $\begin{array}{l}\text { Pule (Alstonia scholaris } \\
\text { R.BR) }\end{array}$ & Root & bark/wood & Sap & Burned \\
\hline 5 & $\begin{array}{l}\text { Sembung (Blumea } \\
\text { balsamifera DC.) }\end{array}$ & - & Leaf, Root & - & Difficulty defecating \\
\hline 6 & Beringin (Ficus benjamina L). & Flower & - & Leaf & $\begin{array}{l}\text { Gonorrhea and acute colitis } \\
\text { tonsillitis }\end{array}$ \\
\hline 7 & $\begin{array}{l}\text { Bajakah (Spatholobus } \\
\text { littoralis Hassk) }\end{array}$ & $\begin{array}{c}\text { Stems, } \\
\text { roots }\end{array}$ & - & - & Cancer \\
\hline 8 & $\begin{array}{l}\text { Banana/Pisang (Musa } \\
\text { paradisiaca } \mathrm{L} \text {.) }\end{array}$ & $\begin{array}{l}\text { Fruit, Stem, } \\
\text { Roots }\end{array}$ & - & - & $\begin{array}{l}\text { Dysentery, intestinal lesions in } \\
\text { hypertension, ulcerative colitis, thrush, } \\
\text { uremia (buildup of urea in the } \\
\text { bloodstream), nephritis, gout, heart } \\
\text { disease. }\end{array}$ \\
\hline 9 & $\begin{array}{l}\text { Kayu Jelema (Knema glauca } \\
\text { Benth. Warb.) }\end{array}$ & - & - & Bark, sap & Joints and paralysis \\
\hline
\end{tabular}

(Source: [7]-[8]-[19]-[23]-[24])

Table 5. Examples of Traditional Medicinal Plants and Potions Mixtures

\begin{tabular}{|c|c|c|c|c|c|}
\hline No & Species & Family & Necessities & $\begin{array}{l}\text { Plant } \\
\text { Parts }\end{array}$ & Mix of Ingredients \\
\hline 1 & $\begin{array}{l}\text { Alstonia scholaris } \\
\text { (L.) R. Br. (Pule) }\end{array}$ & Apocinaceae & $\begin{array}{l}\text { Headache medicine, malaria, } \\
\text { cold (nyem), burns }\end{array}$ & $\begin{array}{l}\text { Bark, } \\
\text { Leaves }\end{array}$ & $\begin{array}{l}\text { Headache: Bark + salt }+ \text { pasture }+ \text { reed } \\
\text { roots }+ \text { candlenut leaves are crushed } \\
\text { and then placed on the forehead, } \\
\text { sprayed on the chest and back. } \\
\text { Malaria: Bark (babakan) + water. } \\
\text { Boiled } \\
\text { Burns: Top of the leaves + sugar + } \\
\text { coconut. Ulig (crushed) and stick }\end{array}$ \\
\hline 2 & $\begin{array}{l}\text { Bischofia javanica } \\
\text { Bl.(Sembung) }\end{array}$ & Euphorbiaceae & Stomach pain (diarrhea) & Leaf & $\begin{array}{l}\text { A handful of sembung leaves }+3 \\
\text { glasses of water. Boiled. Drink it }\end{array}$ \\
\hline 3 & $\begin{array}{l}\text { Averrhoa carambola } \\
\text { L (Belimbing Wuluh) }\end{array}$ & Oxalidaceae & Cough, Congestion & $\begin{array}{l}\text { Leaf, } \\
\text { Fruit }\end{array}$ & $\begin{array}{l}\text { A handful of Starfruit Leaves + Rock } \\
\text { Sugar. Drink it. }\end{array}$ \\
\hline 4 & $\begin{array}{l}\text { Cinnamomum verum } \\
\text { J.S. Presl. } \\
\text { (Kayu Manis) }\end{array}$ & Lauraceae & Cough & $\begin{array}{l}\text { Bark, } \\
\text { Leaf }\end{array}$ & $\begin{array}{l}2 \mathrm{~cm} \text { cinnamon bark, } 3 \text { betel leaves, } 3 \\
\text { cloves, rock sugar, } 3 \text { glasses of water. } \\
\text { Boiled until the remaining } 1 \text { cup. } \\
\text { Drink it }\end{array}$ \\
\hline 5 & $\begin{array}{l}\text { Cocos nucifera } \mathrm{L} \\
\text { ( Kelapa) }\end{array}$ & Arecaceae & $\begin{array}{l}\text { Jaundice, } \\
\text { Intestinal worms, cholera, } \\
\text { vomiting, and itching caused } \\
\text { by smallpox, measles, and } \\
\text { other skin diseases. }\end{array}$ & $\begin{array}{l}\text { Fill } \\
\text { Coconut } \\
\text { Coconut } \\
\text { water }\end{array}$ & $\begin{array}{l}\text { Fill Coconut + Rock Sugar } \\
\text { Coconut water + Santan/ Coconut milk } \\
\text { Drink it }\end{array}$ \\
\hline 6 & $\begin{array}{l}\text { Ficus benjamina } \mathrm{L} . \\
\text { (Beringin) }\end{array}$ & Moraceae & $\begin{array}{l}\text { gonorrhea and acute colitis } \\
\text { Tonsillitis } \\
\text { heat seizures in children }\end{array}$ & $\begin{array}{l}\text { Leaf } \\
\text { Leaf } \\
\text { Leaf }\end{array}$ & $\begin{array}{l}\text { Leaf }+ \text { Water. Boiled. Drink it } \\
\text { Leaf }+ \text { Water }+ \text { Vinegar. Boiled. Drink } \\
\text { it } \\
\text { Leaf }+ \text { Water. Boiled. Take of shower }\end{array}$ \\
\hline 7 & $\begin{array}{l}\text { Spatholobus littoralis } \\
\text { Hassk (Bajakah) }\end{array}$ & Fabaceae & Cancer & $\begin{array}{l}\text { Stems, } \\
\text { Roots }\end{array}$ & $\begin{array}{l}\text { Wood/Stem/Root + Water. Boiled. } \\
\text { Drink it }\end{array}$ \\
\hline 8 & $\begin{array}{l}\text { Musa paradisiaca } \mathrm{L} . \\
\text { (Pisang) }\end{array}$ & Musaceae & $\begin{array}{l}\text { Dysentery, intestinal lesions } \\
\text { in hypertension, ulcerative } \\
\text { colitis, thrush, uremia } \\
\text { (buildup of urea in the } \\
\text { bloodstream), nephritis, gout, } \\
\text { heart disease. }\end{array}$ & $\begin{array}{l}\text { Fruit, } \\
\text { Leaf, } \\
\text { Stem }\end{array}$ & Fruit juice, stem juice, drunk \\
\hline 9 & $\begin{array}{l}\text { Krema glauca Benth. } \\
\text { Warb. } \\
\text { (Kayu Jelema) }\end{array}$ & Myristicaceae & Joints and paralysis & Bark, Sap & $\begin{array}{l}\text { Bark, Sap }+ \text { Alcohol }+ \text { Salt. Rubbed } \\
\text { the part that hurts }\end{array}$ \\
\hline
\end{tabular}

(Source: [7]-[8]-[19]-[23]-[24]) 
Table 6. Medicinal Plants, Chemical Ingredients and Diseases

\begin{tabular}{|c|c|c|}
\hline Plant Species & Chemical Content & Plant Organs \\
\hline Blumea Balsamifera Bl (Sembung) & Burneol, palmitin acid, tannin. & Leaf \\
\hline Averrhoa carambola L (Belimbing Wuluh) & $\begin{array}{l}\text { Leaves: sulfur, formic acid, calcium citrate, tannins } \\
\text { Fruit: protein, ash, fiber or fiber, phosphorus, calcium, iron, } \\
\text { thiamine, carotene, niacin, ascorbic acid, and also flavones }\end{array}$ & $\begin{array}{l}\text { leaf } \\
\text { fruit }\end{array}$ \\
\hline $\begin{array}{l}\text { Cinnamomum zeylanicum Ness (Kayu } \\
\text { Manis) }\end{array}$ & $\begin{array}{l}\text { Essential oils, tannins, resin and lenders, eugenol, safrole, calcium } \\
\text { oxalate, resin, tanning agents }\end{array}$ & Leaf and Bark \\
\hline Cocos nucifera L (Kelapa) & Minerals and sugars (glucose) & $\begin{array}{l}\text { Fill Coconut, } \\
\text { Coconut water }\end{array}$ \\
\hline Alstonia scholaris (L.) R. Br (Pule) & $\begin{array}{l}\text { Alkaloids, saponins, steroids, flavonoids, echitanine, echitamine, } \\
\text { and ditamine }\end{array}$ & Bark and eaf \\
\hline Ficus benjamina L (Beringin) & Tanin, alkaloid dan saponin. & Leaf \\
\hline Spatholobus littoralis Hassk (Bajakah) & $\begin{array}{l}\text { Phenolics, steroids, tannins, alkaloids, saponins, terpenoids, and } \\
\text { alkaloids }\end{array}$ & Stem \\
\hline Musa paradisiaca L. (Pisang) & $\begin{array}{l}\text { Fruit: carbohydrates, protein, fat, fiber, ash, iron, phosphorus, } \\
\text { calcium, potassium, manganese, sodium, nitrogen, zinc and copper. } \\
\text { The content of multivitamins (vitamins A, B complex, C, E) and } \\
\text { multi-elements, such as calcium, magnesium, zinc, selenium. } \\
\text { Roots: norepinephrine, tannins, hydroxytryptamine, dopamine, } \\
\text { vitamins A, B and C. }\end{array}$ & $\begin{array}{l}\text { Fruit } \\
\text { Root } \\
\text { Stem }\end{array}$ \\
\hline $\begin{array}{l}\text { Knema glauca Benth. Warb. } \\
\text { (Kayu Jelema) }\end{array}$ & - & Bark \\
\hline
\end{tabular}

(Source: [7]-[8]-[19]-[23]-[24])

Other research results in refs [28]-[30], the results showed that people's knowledge about medicinal plants was obtained from parents who had long experience in making potions and trading these medicinal plants as traditional herbs. There are three main factors that pose a threat to the preservation of medicinal plants in forest areas in Kalimantan, namely habitat destruction, species scarcity and overexploitation. Conservation of forest medicinal plants can be done in-situ or ex-situ. In the perspective of developing forest tourism [31], in forest management that is carried out by the government, it is always use-oriented and has neglected environmental wisdom (ecological wisdom) and (indigenous people) [32]-[34]. In its study as a whole, it can be stated that the role of local wisdom is very high in protecting forests.

\section{Conclusion}

From the results of this study, it can be concluded that: (1) Overall plant species and medicinal plants in the forest of Taman Gumi Banten, Wanagiri Village, Sukasada District, Buleleng Regency have been mapped. (2) There are 67 species of plants in the forest of Taman Gumi Banten, and 9 species $(15.25 \%)$ are used as medicinal plants. (3) The traditional use of medicinal plants by Balinese people generally has three properties, namely tis (cold), dumelade (not cold and not hot), and anget (hot). (4) Of the 9 species found in the Taman Gumi Banten Forest, it can be used for external and internal medicinal purposes. For external medicine, it is used for reducing fever, cold (nyem), joint disease, paralysis and burns. For internal medicine, it is mainly used to treat stomach aches, heartburn/sore throat, ancer, high blood pressure, malaria drugs, coughs, gonorrhea, tonsillitis, acute colitis and heat seizures. The way it is processed, many medicinal plants are used as loloh (drunk) and boreh (scrub). How to use it, some are by drinking, rubbing, scrubbing/boreh, and patching/pasting. (5) From the perspective of developing forest tourism, it is very open to develop it because supported by the availability of several research results in the form of vegetation maps of species, map of medicine plants, Methods of Utilizing Useful Plants as Medicines, and and supported by the results of previous research in the form of encyclopedia of flora in the forests of Taman Gumi Banten. (6) From a conservation perspective, by discovering several species of medicinal plants and mapping them on a vegetation map, conservation can be carried out by applying local wisdom, religious aspects, myths, and awig-awig (customary village rules). From the above conclusions, there are several recommendations that can be conveyed, namely: (1) In using the forest as a forest tourism object and protecting the forest, the results of this research can be used and applied. (2) Training and assistance by related government agencies in the framework of developing forest tourism and its preservation must still be carried out so that there is a work program that links and matches between village work programs and government work programs.

\section{Acknowledgments}

This work was supported in part by the DIPA BLU from the Universitas Pendidikan Ganesha under Grant 631/UN48.16/LT/2021. 


\section{REFERENCES}

[1] Stern M. J. and Coleman, K. J. “The multidimensionality of trust: Applications in collaborative natural resource management." Society \& Natural Resources, vol. 28, no. 2, pp. 117-132, 2015.

[2] Disser, Y., Ghosh, S. K., Mihalák, M., and Widmayer, P. "Mapping a polygon with holes using a compass." Theoretical Computer Science, vol. 553, pp. 106-113, 2014.

[3] Van Kreveld, M., and Reinbacher, I. "Good NEWS: Partitioning a simple polygon by compass directions." International Journal of Computational Geometry \& Applications, vol. 14, pp. 233-259, 2004.

[4] Sangat, H. M., and Larashati, I. "Some ethnophytomedical aspects and conservation strategy of several medicinal plants in Java, Indonesia." Biodiversitas Journal of Biological Diversity, vol. 3, no. 2, pp. 231-235, 2002.

[5] Chen, S. L., Yu, H., Luo, H. M., Wu, Q., Li, C. F., and Steinmetz, A. "Conservation and sustainable use of medicinal plants: problems, progress, and prospects." Chinese medicine, vol. 11, no. 1, pp. 1-10, 2016.

[6] Cahyaningsih, R., Brehm, J. M., and Maxted, N. "Setting the priority medicinal plants for conservation in Indonesia. Genetic Resources and Crop Evolution," vol. 68, no. 5, pp. 2019-2050, 2021.

[7] Nala. "Usada Bali: Philosophical Review and Its Role in Ecotourism." Seminar Proceedings Conservation of Usada Bali and its Role in Supporting Ecotourism. Eka Karya Bali Botanic Garden, Bali, 2007.

[8] Arsana, I N. "Diversity of Medicinal Plants in Lontar "Taru Pramana" and Their Use for Traditional Balinese Medicine." Jurnal Kajian Bali Journal of Bali Studies, vol. 9, no. 1, pp. 241-262, 2019.

[9] Budiharta, S., Widyatmoko, D., Wiriadinata, H., Partomihardjo, T., Uji, T., Keim, A. P., and Wilson, K. A. "The processes that threaten Indonesian plants." Oryx, vol. 45, no. 2, pp. 172-179, 2011.

[10] Cahyaningsih, R., Brehm, J. M., and Maxted, N. "Gap analysis of Indonesian priority medicinal plant species as part of their conservation planning." Global Ecology and Conservation, vol. 26, e01459, 2021.

[11] BAPPENAS (National Development Planning Agency). Indonesia Biodiversity Strategy and Action Plan. Strategy and Action Plan for Indonesian Biodiversity 2003-2020. Jakarta: BAPPENAS, 2003.

[12] Wijana, N., and Setiawan, I. G. A. N. "Plant Species Mapping and Density in The Village Forest of Penglipuran, Bangli, Bali, Indonesia and Its use in Learning Media." International Journal of Natural Science and Engineering, vol. 1, no. 3, pp. 80-91, 2018.

[13] Wijana, N., and Setiawan, I. G. A. N. "The formation of mini-illustrated dictionary of rare plants in the village forest of Penglipuran, Bangli, Bali." Journal of Physics: Conference Series, vol. 1040, no. 1, 012008, 2018.
[14] Widians, J. A., Wati, M., Tejawati, A., and Budiman, E. "Biodiversity Information System for Management of Medicinal Plants Data Tropical Rainforest Borneo." Int. J. Eng. Technol, vol. 7, no. 4, pp. 31-42, 2018.

[15] Putri, R. I., Supriatna, J., and Walujo, E. B. "Ethnobotanical study of plant resources in Serangan Island, Bali.” Asian J Conserv Biol, vol. 3, no. 2, pp. 135-148, 2014.

[16] Canter, L.W. Environmental Impact Assessment. New York: McGraw-Hill, 1996.

[17] Soenaryanto, R. P. Notes on Simple Mapping of Maps and Boundary Designations. Bogor: Forestry Education and Training Center, 1976.

[18] Wijana, N. "Short Communication; Medicinal plants in Ubud Monkey Forest in Bali, Indonesia: Diversity, distribution, traditional use and tourism attractiveness." Biodiversitas Journal of Biological Diversity, vol. 21, no. 6, pp. 2455-2461, 2020.

[19] Wijana, N., Mulyadiharja, S., and Riawan, I. M. O. "Banten Plants and their Mapping in the Taman Gumi Banten Forest, Wanagiri Village, Sukasada-Buleleng.” Jurnal Pendidikan Biologi undiksha, vol. 7, no. 3, pp. 148-163, 2021.

[20] Dasuka, Y. P. and Hani'ah, B. S. "Analysis of the Distribution of Natural Forest Vegetation Types Using Remote Sensing Systems (Case Study: Wekas and Selo Hiking Trails).” Undip Geodesy Journal, vol. 5, no. 2, pp. 34-42, 2016.

[21] Wijana, N., and Setiawan, I. G. A. N. "Rare Plant Preservation through Village Forest Policy in Bali." In Proceedings of the 2nd International Conference on Innovative Research across Disciplines, 2017.

[22] Wijana, I. N., and Wesnawa, G. A. "The Mapping of Rare Plant Species Distribution in Monkey Forest, Ubud, Gianyar, Bali.” Media Komunikasi Geografi, vol. 19, no. 1, pp. 23-30, 2018.

[23] Hanun, S. F. Exploration of Usada Lontar Medicinal Plants in Klungkung Regency, Bali. Bali: UPT Eka Karya Botanical Garden Bali Conservation Center.

[24] Suryadarma, I G. P. Conservation of Bali Usada Medicinal Plants in an Ecotourism Perspective. Bali: UPT Eka Karya Bali Botanic Garden Plant Conservation Unit-LIPI, 2007.

[25] Andesmora, E. V., Muhadiono, M., and Hilwan, I. "Ethnobotanical study of plants used by people in Hiang Indigenous Forest Kerinci, Jambi.” Journal of Tropical Life Science, vol. 7, no. 2, pp. 95-101, 2017.

[26] Suárez, M. E. "Medicines in the forest: Ethnobotany of wild medicinal plants in the pharmacopeia of the Wichí people of Salta province (Argentina)." Journal of ethnopharmacology, vol. 231, pp. 525-544, 2019.

[27] Nguyen, T. S., Xia, N. H., Van Chu, T., and Van Sam, H. "Ethnobotanical study on medicinal plants in traditional markets of Son La province, Vietnam.” Forest Soc, vol. 3, no. 2, pp. 171-92, 2019.

[28] Falah, F., and Hadiwibowo, N. "Species identification of traditional medicine plants for women's health in East Kalimantan: lesson learned from local wisdom.” Indonesian Journal of Forestry Research, vol. 4, no. 1, pp. 49-67, 2017. 
[29] Malini, D. M., Madihah, M., Kusmoro, J., Kamilawati, F., and Iskandar, J. "Ethnobotanical study of medicinal plants in Karangwangi, District of Cianjur, West Java." Biosaintifika: Journal of Biology \& Biology Education, vol. 9, no. 2, pp. 345-356, 2017.

[30] Dewantara, A. I. and Herawatiningsih, R. "Types and Potential of Medicinal Plants in the Traditional Forest Area of Mount Semarong, Tayan Hulu District, Sanggau Regency." Sustainable Forest Journal, vol. 3, no. 3, pp. 446 $-455,2015$.

[31] Suarmana, I W. R. and Mahagangga, I. G. A. O. "Contribution of Monkey Forest Tourism Attraction in the Prosperity of Local Communities in Padang Tegal Village,
Ubud District.” Journal of Destinasi Pariwisata, vol. 2, no. 2 , pp. 13-28, 2014.

[32] Henri, H., Hakim, L., and Batoro, J. "Ecotourism Development Strategy of Pelawan Forest in Central Bangka, Bangka Belitung." Journal of Indonesian Tourism and Development Studies, vol. 5, no. 3, pp. 145-154, 2017.

[33] Pawar, K. V., and Rothkar, R. V. "Forest conservation \& environmental awareness." Procedia Earth and Planetary Science, vol. 11, pp. 212-215, 2015.

[34] Yuniati, D., and Khotimah, H. "Local Wisdom and Practice of Bamboo Forest Management in Bali Community.” Jurnal Penelitian Sosial dan Ekonomi Kehutanan, vol. 13, no. 1, pp. 63-72, 2016. 